
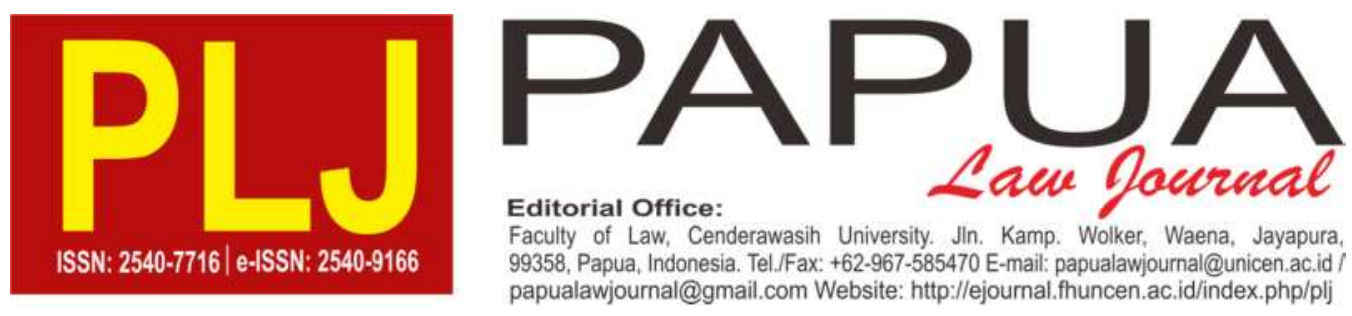

\title{
Special Autonomy Papua: Compliance Against Applicable Rules/Guidelines (Case Study In Jayapura City)
}

\author{
Marsi Adi Purwadi \\ Faculty of Economic and Bussinis, Cenderawasih University \\ Jl. Kamp Wolker, Waena, Jayapura, 99358, Papua Indonesia \\ Tel./Fax :+62-852 4456 2062, Email: marsipurwadi@gmail.com
}

\begin{abstract}
The main purpose of this study is to identify and analyze the implementation of activities financed by the Special Autonomy Fund whether it is in accordance with existing rules/guidelines, whether it is seen from the routine activities, the funds used in each activity, the leverage of the implementation of activity towards the achievement the vision and mission of the regional head, the involvement of the Papuans in the activities, and the influence of the implementation of the activities towards solving the problems of the Local people. Methods used include: Quantitative descriptive statistics in the form of concentration measures, and crosstab analysis. Based on the results of this study it can be concluded that: 1) During the period of 2008-2014 the implementation of programs/activities classified routinely carried out all almost been implemented with reference to the rules / guidelines of the implementation of Special Autonomy in Papua Province; 2) Development Programs /Activities implemented through the use of Special Autonomy funds, indicating the amount of activities that use substantial amount of funds and the implementation is in accordance with the rules/guidelines of the implementation of Special Autonomy in Papua Province; 3) Implementation of development activities using Special Autonomy funds in Jayapura City has been able to play a role in improving the achievement of vision and mission of regional head, whose implementation has been in accordance with existing rules/guidelines; 4) The results of this study indicate that many programs/activities involving the implementation of many Orang Asli Papua, whose implementation has been in accordance with existing rules/guidelines; 5) Implementation of Special Autonomy policy in Papua Province is expected to solve the problems faced by Orang Asli Papua. The results of this study indicate that most of the activities undertaken by the Jayapura City Government using Special Autonomy funds have had an impact/change in alleviating the problems/problems faced by Local People, whose implementation has been in accordance with existing rules/guidelines.
\end{abstract}

Keywords: Compliance Rules; Special Autonomy; Local People. 


\section{INTRODUCTION}

The Special Autonomy Law was the result of a bargain between the people of Papua and the Government of Indonesia on 26 February 1999 at the State Palace when 100 official delegates, representing elements in Papua led by Thomas Beanal, met President BJ Habibie. But President Habibie did not give support to the request. This urging finally got a "fresh air" when President Abdurrahman Wahid gave support to reuse the name of Papua in exchange for Irian Jaya, and granting permission to use the Morning Star flag as a provincial flag ${ }^{1}$.

Answering the demand for independence, the State and the Government offer special autonomy for the Papua Province. Where special autonomy for Papua Province was first formulated in the Decree of MPR RI Number IV / MPR / 1999 on GBHN 1999-2004. In point IV The Direction of Policy G on the Development of the Region is mentioned "political offer" to the Papuan people about "Special

1 Agung Djojosoekarto, 2008. Kinerja Otonomi Khusus Papua, Kemitraan bagi Pembaruan Tata Pemerintahan di Indonesia, Jakarta. Media Utama, p. 30
Autonomy". The Decree of the People's

Consultative Assembly reads ${ }^{2}$ :

"In the framework of the development of regional autonomy within the NKRI, and to solve equally and comprehensively the problems in the region (Irian Jaya) that require immediate and serious handling, it is necessary to take the following steps: (1) To maintain the integration of the nation in in NKRI while respecting the equality and diversity of social and cultural life of the Irian Jaya community through the establishment of special autonomous regions regulated by law, (2) Resolving cases of human rights violations in Irian Jaya through an honest and dignified court process ".

In the course of time, the granting of special autonomy to the Papua Provincial is considered to be a strategic policy that helps improve the economy of the Papuan people, promotes accelerated development, and improves public services. Furthermore, with the existence of Otsus Papua is also expected to reduce the gap between Papua Province with other provinces within the framework of NKRI in terms of education, health and basic infrastructure, and economic growth

\footnotetext{
2 Ketetapan Majelis Permusyawaratan Rakyat Republik Indonesia Nomor: IV/MPR/1999 Tentang Garis-Garis Besar Haluan Negara Tahun 1999 - 2004.
} 
Special autonomy of Papua during the period 2001-2016 implemented in Papua Province is based on:

1. Law No.21 of 2001 on Special Autonomy for Papua Province.

2. Government Regulation in Lieu of Law No. 1 of 2008 on amendment of Law Number 21 Year 2001 on Special Autonomy for Papua Province.

3. Law No. 35 of 2008 on Stipulation of Government Regulation in Lieu of Law No. 1 of 2008 on amendment to Law No.21 of 2001 on Special Autonomy for Papua Province.

4. PERDASUS 25 Year 2013 on the Distribution of Admissions and Management of Papua's Special Autonomy Fund.

Operationalization of PERDASUS $25 / 2013$ has been followed up with the stipulation of implementation rules in the form of Governor Regulation and Governor's Decree. Some of the implementing regulations are:

1. Governor Regulation 32 Year 2014 on Directive for Implementation and Use of Special Autonomy Fund of Education for Regency / City in Papua Province

2. Governor Regulation No. 6 of 2014 on Financing Guarantee for Papua Public Health Services

3. Governor Regulation No. 8 of 2014 on Technical Guidelines for the Use of Special Autonomy Fund for Health Sector at $15 \%$ for Regency / City within Papua Province.
4. Governor Regulation No. 16 of 2014 on Guidelines for Strategic Management of Economic and Institutional Development Program of Kampung Tahun 2014.

5. Governor Regulation No. 30 of 2015 on Allocation of Special Autonomy Funds of Regency / City $\mathrm{Se}$ of Papua Province Budget Year 2015

6. Governor's Decree Number 466 of 2014 on Approval of Provision of Funds for Development and Development of Religious Institutions in Papua Province for Fiscal Year 2014.

Law Number 21 Year 2001 is a general policy framework that guides the implementation of Special Autonomy in Tanah Papua. This law regulates the various basic sectors that are part of the implementation of Special Autonomy. The sectors regulated in this law create a specific character in the direction of regional policy in Papua which distinguishes it from other regions in NKRI.

That the philosophical formation of Law No.21 of 2001 contains moral, ideological, political and social consequences, therefore at the level of implementation of special autonomy to be more effective, efficient, open, aspirational, real and responsible in 
advancing the welfare of indigenous Papuans.

On the basis of this, the government of Jayapura City gained widespread authority to make policies and mechanisms more real or real according to the needs of the community and synchronized with the variables and vision of the regional head, especially the allocation of financing to be consistent and obedient to the mandate of the Autonomy Law special.

The use of guidelines as the basis for the preparation of the program / activity plan is an obligation that must and must be done by every local government in Papua, including the government of Jayapura City. With reference to the guidelines in the form of established legal regulations it is expected that the implementation of Special Autonomy in Papua can proceed in the desired direction.

During the period of 2008-2016, the city government of Jayapura has implemented many programs/activities with funding using the Special Autonomy Fund. This is of course an important part in the development of a more dignified Papuan human being. Good identification can provide an overview of the direction of implementation of Special Autonomy policy that has been going on for this in Jayapura City.

The objectives of this research are: 1) identifying and analyzing the routine of activities whose execution has been in accordance with existing guidelines; 2) identify and analyze the funds used for which the execution has been in accordance with existing guidelines; 3 ) identify and analyze activities that have leverage to the achievement of the vision and mission of the regional head that the implementation has been in accordance with existing guidelines; 4) identifying and analyzing the involvement of indigenous Papuans in activities that have performed in accordance with existing guidelines; 5) identify and analyze activities that affect the settlement of Papua Orang Asli problems whose execution has been in accordance with existing guidelines.

\section{METHODS OF THE RESEARCH}

The type of research is normativelegal research, which is used to study the rules of law or legal provisions with emphasis on the principles of law that relating to the Special Autonomy and 
Local people in Papua, especially related to the interaction between them.

The technique of data collection used is literature study, by studying various legal materials includes primary, secondary, and tertiary in accordance with the object of study. Data analysis is done by analyzing qualitative data by reducing data, presenting data and drawing conclusion.

\section{ANALYSIS AND DISCUSSION}

Geographically Jayapura City has an area of $924 \mathrm{~m}^{2}$ or $0.30 \%$ of Papua province. Jayapura city has 5 districts, 29 sub-districts and 14 villages. The population of Jayapura City in 2013, recorded as many as 272,544 people or increased by 1.58 percent from the previous year. With an area of $940 \mathrm{~km}^{2}$ means the population density of Jayapura City $290 \mathrm{soul} / \mathrm{km}^{2}$. From the whole kampong in Jayapura City, culturally is the native Papuan villages of Tobati-Enggros, Skow, Nafri, Kayu Pulau, Kayu Batu and Sentani have customary rights in the city of Jayapura or known as the Port People Numbay or Tabi land.

As the Capital of the Province, Jayapura City has Characteristics of
Heterogeneous society. Various tribes in Indonesia and even in other Papua region berurbanisasi to the city of Jayapura, by reason of work, education and even as a transit city to visit other areas in the region of Papua.

During the period of 2008-2014, the government of Jayapura City has implemented 810 activities with the financing allocated through the Special Autonomy fund. During that period, implementation of the implementation of Special Autonomy in Jayapura City has shown good condition. This is evident from the many activities undertaken by the Jayapura City Government whose financing is allocated through the Special Autonomy Fund, which is distributed to 29 SKPD managers of the Special Autonomy Fund.

Education Office is SKPD with the largest distribution of activities, as many as 219 activities, followed by Dinas Kesehatan with the distribution of activities as much as 147 activities. This indicates that SKPD-SKPD that is related to the priority areas mandated by the Special Autonomy Policy, has gained a large share. 
Table 1

Distribution of Activities Funded by Dana Otsus Kota Jayapura According to SKPD Year 2008-2014

\begin{tabular}{|c|c|c|c|c|c|c|c|c|c|}
\hline No & Agencies & 2008 & 2009 & 2010 & 2011 & 2012 & 2013 & 2014 & Total \\
\hline 1 & Dinas Pendidikan & 26 & 35 & 33 & 25 & 37 & 47 & 16 & 219 \\
\hline 2 & Dinas Kesehatan & 13 & 13 & 16 & 24 & 30 & 29 & 22 & 147 \\
\hline 3 & Badan Pemberdayaan Perempuan \& KB & 3 & 6 & 6 & 11 & 7 & 13 & 8 & 54 \\
\hline 4 & Dinas Pekerjaan Umum & 3 & 7 & 5 & 9 & 6 & 12 & 8 & 50 \\
\hline 5 & Dinas Sosial & 5 & 10 & 6 & 8 & 7 & 8 & 6 & 50 \\
\hline 6 & Dinas Pertanian & & & & 7 & 4 & 13 & 8 & 32 \\
\hline 7 & Badan Pemberd. Masy. \& Pem. Kampung & & 2 & 5 & 4 & 3 & 11 & 6 & 31 \\
\hline 8 & DISPERINDAGKOP & 3 & 6 & 3 & 5 & 3 & 9 & & 29 \\
\hline 9 & DKPP & 1 & 4 & 3 & 7 & 10 & 1 & 2 & 28 \\
\hline 10 & Dinas Kelautan Dan Perikanan & & & 1 & 4 & 2 & 11 & 9 & 27 \\
\hline 11 & Sekertariat Daerah & 6 & 1 & 4 & 5 & 4 & & & 20 \\
\hline 12 & Dinas Tenaga Kerja & 6 & 2 & 3 & 3 & 1 & 2 & 2 & 19 \\
\hline 13 & Dinas Kebudayaan Dan Pariwisata & & & 2 & 1 & 1 & 8 & 5 & 17 \\
\hline 14 & Kantor Ketahanan Pangan \& Penyuluhan & & & 1 & 3 & 1 & 7 & 3 & 15 \\
\hline 15 & Dinas Pemuda Dan Olahraga & & 3 & 2 & 1 & 2 & 5 & & 13 \\
\hline 16 & Dinas Kependudukan \& Pencatatan Sipil & 6 & & 2 & 3 & 1 & & & 12 \\
\hline 17 & BAPPEDA & 2 & 1 & 1 & 1 & 1 & 1 & 1 & 8 \\
\hline 18 & Distrik Abepura & 1 & 1 & 1 & 1 & 1 & & & 5 \\
\hline 19 & Distrik Heram & 1 & 1 & 1 & 1 & 1 & & & 5 \\
\hline 20 & Distrik Jayapura Selatan & 1 & 1 & 1 & 1 & 1 & & & 5 \\
\hline 21 & Distrik Jayapura Utara & 1 & 1 & 1 & 1 & 1 & & & 5 \\
\hline 22 & Distrik Muara Tami & & 1 & 1 & 1 & 1 & & & 4 \\
\hline 23 & Badan Kesbang, Politik Dan Linmas & 1 & & & 2 & & & & 3 \\
\hline 24 & Dinas Informasi Dan Komunikasi & 2 & 1 & & & & & & 3 \\
\hline 25 & Dinas Perhubungan & & & & 2 & 1 & & & 3 \\
\hline 26 & Dinas Kehutanan & & & & & & 2 & & 2 \\
\hline 27 & Dinas Ketentraman Dan Ketertiban & & & & 2 & & & & 2 \\
\hline 28 & Badan Lingkungan Hidup Daerah & & & & & 1 & & & 1 \\
\hline 29 & Badan Pengelola Keuangan \& Aset Daerah & 1 & & & & & & & 1 \\
\hline Total & & 82 & 96 & 98 & 132 & 127 & 179 & 96 & 810 \\
\hline
\end{tabular}

Education is the area of financing with the largest number of activities financed by the Special Autonomy Fund of Jayapura City. During the period of 2008-2014, the government of Jayapura City has allocated Special Autonomy fund to increase education development towards Orang Asli Papua through 222 activities. Planning and Monev is the financing field with the lowest number of activities with 18 activities.

Infrastructure during the period, only allocated funds for activities as 
many as 26 activities. The amount is very small when compared with other fields because in the period 2008-2013 there is no clear provision on the use of the Special Autonomy Fund for
Infrastructure Sector, especially the categorization of infrastructure that must be financed by the Special Autonomy fund.

Table 2.

Number of Activities Funded by Special Autonomy Kota Jayapura According to Priority Sector Year 2008-2014

\begin{tabular}{cccccccccc}
\hline No & \multicolumn{1}{c}{ Area } & $\mathbf{2 0 0 8}$ & $\mathbf{2 0 0 9}$ & $\mathbf{2 0 1 0}$ & $\mathbf{2 0 1 1}$ & $\mathbf{2 0 1 2}$ & $\mathbf{2 0 1 3}$ & $\mathbf{2 0 1 4}$ & Total \\
\hline $\mathbf{1}$ & Education & 26 & 35 & 33 & 25 & 34 & 51 & 18 & 222 \\
\hline $\mathbf{2}$ & Health & 18 & 15 & 18 & 28 & 32 & 29 & 24 & 164 \\
\hline $\mathbf{3}$ & Society Economy & 5 & 10 & 11 & 24 & 14 & 39 & 23 & 126 \\
\hline $\mathbf{4}$ & Afirmation & 4 & 7 & 8 & 12 & 6 & 19 & 11 & 67 \\
\hline $\mathbf{5}$ & Basic Infrastructure & 1 & 3 & 1 & 5 & 6 & 6 & 4 & 26 \\
\hline $\mathbf{6}$ & Planning and Monev & 2 & 2 & 2 & 1 & 5 & 5 & 1 & 18 \\
\hline $\mathbf{7}$ & Others & 26 & 24 & 25 & 37 & 30 & 30 & 15 & 187 \\
\hline & Total & $\mathbf{8 2}$ & $\mathbf{9 6}$ & $\mathbf{9 8}$ & $\mathbf{1 3 2}$ & $\mathbf{1 2 7}$ & $\mathbf{1 7 9}$ & $\mathbf{9 6}$ & $\mathbf{8 1 0}$ \\
\hline
\end{tabular}

The use of the Special Autonomy Allocation Fund of Jayapura City shall be based on Perdasus No. 25 of 2013 on the Distribution and Management of Special Autonomy Funds, Part Five on the Allocation of Special Autonomy Funds of Regency/Municipality Article 11 Paragraph 1, wherein its alocation is as follows:

1. Education (Early Children Education, Elementary Eduction 9 Years, Middle and High) allocated by $30 \%$;

2. Health (basic health, referral health, prevention \& eradication, community nutrition, counseling \& sanitation, health in disaster situation) amounting to $15 \%$;

3. Community economy (business credit, revolving fund, subsidized price of foodstuff, commodity seed) as much as $20 \%$;

4. Basic Infrastructure (public housing, lighting, clean water, telecommunication) by $20 \%$;

5. Affirmation Assistance (religious, indigenous peoples, women's groups) of 6\%; and

6. Planning and $M \& E$ (planning \& monitoring, monitoring \& evaluation, program \& activity reporting) by $4 \%$.

Although during the period of 2008-2014 the number of activities carried out using the Special Autonomy Fund is 810 activities, but the amount is an accumulation of activities undertaken by the Jayapura City Government during that period. While in the implementation during the time period was recorded only as many as 
321 activities whose source of financing comes from the Special Autonomy fund, or in other words almost most of the activities are activities that are almost routinely done every year.

He use of the Special Autonomy Allocation Fund of Jayapura City shall be based on Perdasus No. 25 of 2013 on the Distribution and Management of Special Autonomy Funds, Part Five on the Allocation of Special Autonomy Funds of Regency / Municipality Article 11 Paragraph 1, wherein its alocation is as follows:

1. Education (Paud, Dikdas 9 Years, Middle and High) allocated by $30 \%$;

2. Health (basic health, referral health, prevention \& eradication, community nutrition, counseling \& sanitation, health in disaster situation) amounting to $15 \%$;

3. Community economy (business credit, revolving fund, subsidized price of foodstuff, commodity seed) as much as $20 \%$;

4. Basic Infrastructure (public housing, lighting, clean water, telecommunication) by $20 \%$;

5. Affirmation Assistance (religious, indigenous peoples, women's groups) of $6 \%$; and

6. Planning and $\mathrm{M} \& \mathrm{E}$ (planning \& monitoring, monitoring \& evaluation, program \& activity reporting) by $4 \%$.

Although during the period of 2008-2014 the number of activities carried out using the Special Autonomy Fund is 810 activities, but the amount is an accumulation of activities undertaken by the Jayapura City Government during that period. While in the implementation during the time period was recorded only as many as 321 activities whose source of financing comes from the Special Autonomy fund, or in other words almost most of the activities are activities that are almost routinely done every year.

Table 3.

Number of Activities Implemented Using Special Autonomy Fund According SKPD Year 2008-2014

\begin{tabular}{lc}
\hline \multicolumn{1}{c}{ SKPD/Department } & AMOUNT \\
\hline Dinas Pendidikan & 69 \\
\hline Dinas Kesehatan & 33 \\
\hline Badan Pemberdayaan Perempuan dan Keluarga Berencana & 25 \\
\hline Dinas Sosial & 23 \\
\hline Dinas Pertanian & 21 \\
\hline Dinas Pekerjaan Umum & 19 \\
\hline Badan Pemberdayaan Masyarakat dan Pemerintahan Kampung & 15 \\
\hline Dinas Kebersihan, Pertamanan dan Pemakaman & 14 \\
\hline Dinas Kelautan dan Perikanan & 14 \\
\hline
\end{tabular}




\begin{tabular}{lc}
\hline \multicolumn{1}{c}{ SKPD/Department } & AMOUNT \\
\hline Dinas Kebudayaan dan Pariwisata & 13 \\
\hline Sekretariat Daerah & 12 \\
\hline Dinas Tenaga Kerja & 10 \\
\hline Dinas Perindustrian, Perdagangan dan Komunikasi & 9 \\
\hline Dinas Pemuda dan Olahraga & 8 \\
\hline Kantor Ketahanan Pangan dan Penyuluhan & 8 \\
\hline Dinas Perhubungan & 7 \\
\hline Dinas Tata Kota dan Pertamanan & 5 \\
\hline Dinas Kependudukan dan Pencatatn Sipil & 4 \\
\hline Badan Kesatuan Bangsan dan Politik & 3 \\
\hline Satuan Polisi Pamong Praja (Satpol PP) & 2 \\
\hline Badan Lingkungan Hidup & 1 \\
\hline Badan Pengelola Keuangan dan Aset Daerah & 1 \\
\hline Badan Perencanaan dan Pembangunan Daerah & 1 \\
\hline Distrik Abepura & 1 \\
\hline Distrik Jayapura Selatan & 1 \\
\hline Distrik Jayapura Utara & 1 \\
\hline Distrik Muaratami & 1 \\
\hline Grand Total & $\mathbf{3 2 1}$ \\
\hline
\end{tabular}

The conformity of the program / activity implementation in Jayapura City with the rules and guidance is seen from 5 aspects, among others: (1) the activity routine, (2) the amount of funds managed, (3) the relation with the vision and mission of the head of region, (4) involvement of $\mathrm{OAP}$ in activities, (5) its impact on the settlement of OAP problems in Jayapura City. In the context of the

Table 4.

Principle of Compliance in Program/Activity Planning derived from Special Autonomy Fund (OTSUS) in Jayapura City

Activities which are appropriate and / or sufficient in accordance with the existing guidelines should receive a large portion for routine Principle of Precision 1 implementation every year. Conversely, for those who are not in accordance with existing guidelines enough to be implemented once or twice, even should not be implemented

Principle of Competence 2
Activities which are appropriate and / or sufficient in accordance with existing guidance shall receive substantial and / or substantial portions of funds in their implementation. Conversely for the less in accordance with the existing guidelines enough given a small fund, even better should not 
be funded.

Activities which are appropriate and / or sufficient in accordance with existing guidance shall be capable of being high leverage and or in

Principle of Precision 3 achieving the vision and mission of the regional head. Conversely for the less in accordance with the existing guidelines only have low leverage, even no leverage.

Activities which are appropriate and / or sufficient in accordance with the existing guidelines should involve more or more OAP in their implementation. While activities that involve little OAP need to be

Principle of Precision 4 considered not to be implemented, or made adjustments / changes in accordance with existing guidelines.

Activities which are appropriate and / or sufficient in accordance with the existing guidelines should be able to be a high thrust and or are in the

Principle of Precision 4 process of solving the OAP problems. Whereas for activities with low impetus to solving OAP problems need to be considered not implemented, or adjustments / changes in accordance with existing guidelines.

Implementation of PERDASUS No. 25/2013 relating to the implementation of programs / activities sourced from OTSUS funds, suggests that the process of preparing the work plan needs to pay attention to the linkages and consistency between planning, budgeting, implementation, administration, accountability, reporting and supervision of the use of
Special Autonomy funds. There is a key phrase in article 15, paragraph 4, that the Program and activities in the work plan of the use of special autonomy funds by SKPD in the Regency/City should specify separately the funding of programs and activities sourced from OTSUS funds in the proposed definitive plan (URD) as part of the plan work SKPD Regency/City.

Table 5.

Crostab Compliance Implementation of Activities With Rules/Guidelines Which With Performance Activity Routine Per Year

\begin{tabular}{lcccc}
\hline \multicolumn{1}{c}{$\begin{array}{c}\text { Appropriateness of } \\
\text { Implementing Activities With } \\
\text { Existing Rules / Guideline }\end{array}$} & ALWAYS & SOMETIMES & RARE & Total \\
\cline { 2 - 5 } & & & & \\
\hline Corresponding & 54 & 28 & 16 & 107 \\
\hline Simply Match & 54 & 0 & 3 & 211 \\
\hline Less Match & 0 & 35 & 178 & 321 \\
\hline Grand Total & 108 & \multicolumn{3}{c}{ Routine Activity } \\
\hline
\end{tabular}


There are still many activities whose implementation is sufficiently consistent with existing guidelines, but rarely implemented during the period 2008-2014. Based on the above mentioned principles, it is fitting that activities which are appropriate and / or sufficient in accordance with existing guidelines should receive a large portion to be carried out routinely every year. Conversely, for those who are not in accordance with existing guidelines enough to be implemented once or twice, even should not be implemented.

From the table above also seen that as many as 129 activities are rarely done, but the implementation of these activities quite in accordance with existing guidelines. While there are 46 activities whose implementation has been in accordance with existing guidelines, but these activities are rarely done.

The frequent execution of activities in accordance with existing rules/guidelines, indicates that the Jayapura City Government has implemented the principle of compliance with legislation which is also an important part in the management of local/state finances. This of course became one of the indicators of success in the implementation of Special Autonomy in Jayapura City.

Table 6.

Crostab Compliance Implementation of Activities With Existing Rules/Guidelines With Funds Used To Conduct Activities

\begin{tabular}{|l|c|c|c|c|}
\hline \multirow{2}{*}{$\begin{array}{c}\text { Appropriateness of } \\
\text { Implementing Activities With } \\
\text { Existing Rules / Guideline }\end{array}$} & HUGE & BIG & SMALL & Total \\
\cline { 2 - 5 } & 54 & 49 & 4 & 107 \\
\hline Corresponding & 18 & 156 & 37 & 211 \\
\hline Simply Match & 0 & 0 & 3 & 3 \\
\hline Less Match & 72 & 205 & 44 & 321 \\
\hline Grand Total & & & & \\
\hline
\end{tabular}

Based on philosophical formation of Law no. 21 of 2001 and PERDASUS No. 25 of 2013 on the distribution and management of Special Autonomy funds for the Regency and City (Article 11 paragraph 1) and consider the consideration in the regulation of the Act, whether it is absolute and mutual affairs (Concurrent), obligatory affairs (Obligatory) regulates basic services and services that are affirmations or alignments. 
During the period of 2008-2014, there are still many activities that the implementation is quite in accordance with the existing guidelines, but the implementation only uses a small amount of funds. Based on the above mentioned principle, it is fitting that the activities which are implemented accordingly and/or sufficiently in accordance with the existing guidelines should receive a large and/or substantial portion of funds in the implementation. Conversely for the less in accordance with the existing guidelines enough given a small fund, even better should not be funded.

From the table above also seen that as many as 156 activities that funding is large enough in carrying out activities, where the implementation of these activities quite in accordance with existing guidelines. Whereas there are only 4 activities that use only small funds, but the implementation of these activities in accordance with the existing guidelines.

Compliance with rules/guidelines relating directly to the implementation of Special Autonomy has been reflected in the allocation of Special Autonomy funds to each of the existing development activities, and in the execution of these activities are mostly done using substantial funds. This means that the Jayapura City Government has been wise (efficient and effective) in allocating funds for each activity undertaken, and in the execution of these activities in accordance with existing rules/guidelines. This is of course a success in the implementation of Special Autonomy policy in Jayapura City.

Table 7.

Crosstab Conformity of Implementation of Activities With Existing Rules/Guidelines With Power Ungkit To Achievement Vision And Mission Leadership Area

\begin{tabular}{lcccc}
\hline \multirow{2}{*}{$\begin{array}{c}\text { Appropriateness of } \\
\text { Implementing Activities With } \\
\text { Existing Rules / Guideline }\end{array}$} & \multicolumn{2}{c}{ Achievement for Vision And Mission Leadership Area } \\
\cline { 2 - 5 } & HIGH & MIDDLE & LOW & Total \\
\hline Corresponding & 93 & 14 & 0 & 107 \\
\hline Simply Match & 69 & 128 & 14 & 211 \\
\hline Less match & 0 & 0 & 3 & 3 \\
\hline Grand Total & 162 & 142 & 17 & 321 \\
\hline
\end{tabular}


There are many activities in which the implementation is sufficiently consistent with the existing guidelines, but the implementation has only moderate leverage over the vision and mission of the regional head during the period of 2008-2014. Based on the above-mentioned principle, it is fitting that activities which are appropriate and/or sufficient in accordance with existing guidelines should be able to be a high leverage and or are in the achievement of the vision and mission of the regional head. Conversely for the less in accordance with the existing guidelines only have low leverage, even no leverage.

From the table above also seen that as many as 128 activities that have a leverage that is, where the implementation of these activities quite in accordance with existing guidelines. While there are only 14 activities whose implementation is only able to have low leverage, but the implementation of these activities quite in accordance with existing guidelines.

In an effort to improve development in line with the vision and mission of the regional head in Jayapura City and which has been in accordance with the rules/guidelines applicable and adopted in Special Autonomy, development activities using the Special Autonomy Fund have also contributed considerably. On the other hand, the ability to be one of the leverage in achieving the vision and mission of regional head still need to be revisited, because there are still 142 activities that have leverage which is in achievement of vision and mission of regional head, which should be optimized to become a strategic leverage in achieving development in the city of Jayapura.

Table 8.

Crosstab Conformity of Implementation of Activities With Existing Rules/Guidelines With OAP Engagement (Orang Asli Papua) In Activities

\begin{tabular}{lcccc}
\hline $\begin{array}{c}\text { Appropriateness of } \\
\text { Implementing Activities With } \\
\text { Existing Rules / Guideline }\end{array}$ & \multicolumn{2}{c}{ Involvement of OAP (Orang Asli Papua) In Activity } \\
\cline { 2 - 5 } & PLENTY & MANY & FEW & Total \\
\hline Corresponding & 33 & 71 & 3 & 107 \\
\hline Simply Match & 7 & 197 & 7 & 211 \\
\hline Less Match & & 1 & 2 & 3 \\
\hline Grand Total & 40 & 269 & 12 & 321 \\
\hline
\end{tabular}


Almost most of the activities are activities that are adequately implemented in accordance with the existing guidelines, which in the implementation of these activities pretty much involve Orang Asli Papua. Based on the above mentioned principles, it is fitting that activities which are appropriate and/or sufficient in accordance with existing guidelines should involve more or more OAP in their implementation. While activities that involve little OAP need to be considered not to be implemented, or made adjustments/changes in accordance with existing guidelines.

From the table above shows that as many as 197 activities which in its implementation involve quite a lot of Orang Asli Papua, the implementation of these activities quite in accordance with existing guidelines. While there is only one activity that in its implementation involves quite a lot of Orang Asli Papua, but the implementation of these activities is less in accordance with existing guidelines.

Although the above conditions indicate that there are quite enough activities in accordance with the rules/guidelines related to Special Autonomy, however the implementation of programs / activities that use the Special Autonomy Fund mostly involves only a considerable number of Orang Asli Papua in its implementation, as many as 269 activitie . While activities involving many indigenous people of Papua are recorded only as many as 40 activities, which should be the activities undertaken Jayapura City Government in relation to Special Autonomy should involve many Orang Asli Papua. Since the objective of development within the Special Autonomy policy in the Papua Province is the development of Orang Asli Papua, one of the easiest implementation is to involve many Orang Asli Papua in every activity financed by using the Special Autonomy Fund. 
Table 9.

Crosstab Compliance Implementation of Activities With Existing Rules/Guidelines With Its Effect On Settling Problems OAP (Orang Asli Papua)

\begin{tabular}{lcccc}
\hline \multirow{2}{*}{$\begin{array}{c}\text { Appropriateness of } \\
\text { Implementing Activities With } \\
\text { Existing Rules / Guideline }\end{array}$} & \multicolumn{4}{c}{ The Effect of Solving OAP Problems } \\
\cline { 2 - 5 } Corresponding & HIGH & MIDDLE & LOW & Total \\
\hline Simply Match & 16 & 62 & 29 & 107 \\
\hline Less Match & 11 & 176 & 24 & 211 \\
\hline Grand Total & & 2 & 1 & 3 \\
\hline
\end{tabular}

During the period of 2008-2014, most of the activities are activities that are sufficiently well-suited to the existing guidelines, in which the implementation of these activities has a moderate effect on solving Papuan Orang Asli problems. Based on the above mentioned principle, it is fitting that activities which are appropriate and/or sufficient in accordance with the existing guidance shall be capable of a high thrust and/or in solving the OAP problems. Whereas for activities with low impetus to solving OAP problems need to be considered not implemented, or adjustments/changes in accordance with existing guidelines.

From the above table it can be seen that as many as 176 activities are capable of having a thrust of being in solving the problems of Orang Asli Papua, where the implementation of these activities is sufficient in accordance with existing guidelines. Whereas there are 29 activities which in practice are able to have a low thrust in solving the problems of OAP Orang Asli Papua, but the implementation of these activities in accordance with existing guidelines.

However, the implementation of programs/activities using the Special Autonomy Fund is mostly only in the moderate category in alleviating the problems faced by Orang Asli Papua, which are 240 activities. While activities that have a high influence on solving the problems of Orang Asli Papua are only 27 or fewer when compared with activities that have only low influence on solving the problems of Orang Asli Papua which recorded as many as 54 activities.

\section{CONCLUSION}

1. During the period of 2008-2014 the implementation of programs/activities classified routinely done all almost been implemented with guidance on the 
rules/guidelines of the implementation of Special Autonomy in Papua Province. This indicates that the implementation of development undertaken by the Jayapura City Government during that time period has really reflected the Papuan Orang Asli development effort.

2. Programs/Activities of development implemented by using Special Autonomy funds, indicating the amount of activities that use large amount of funds and the implementation is in accordance with the rules/guidelines of the implementation of Special Autonomy in Papua Province. This is certainly a form of accountability in the implementation of development that is able to create a sense of trust of the Orang Asli Papua to continue to help fight for the success of Special Autonomy in Papua.

3. Implementation of programs/activities using Special Autonomy fund also directly have leverage to the achievement of vision and mission of regional head, fund in this research have been proved that implementation of development activity using Special Autonomy fund in Jayapura City has been able to play a role in increasing development in City of Jayapura through the achievement of vision and mission of regional head. However, it should be noted the synergy between the use of conformity with the existing rules/guidelines with the achievement of the vision and mission of the regional head, so as to realize the optimal development but obey the rules.

4. One of the expectations of the implementation of the Special Autonomy policy in the Papua Province is to build the Orang Asli Papua from its backwardness. The results of this study indicate that many programs/activities involving the implementation of many Orang Asli Papua. This of course can be an important part in the effort to improve the spirit of the Orang Asli Papua to engage and/or actively involve themselves in the development process in Papua.

5. Implementation of Special Autonomy policy in Papua Province is expected to solve the problems faced by Orang Asli Papua. The 
results of this study indicate that most of the activities undertaken by the Government of Jayapura City using Special Autonomy funds have had an impact/change in alleviating the problems/problems faced by Orang Asli Papua.

\section{BIBLIOGRAPHY}

Agung Djojosoekarto, 2008. Kinerja Otonomi Khusus Papua, Kemitraan bagi Pembaruan Tata Pemerintahan di Indonesia, Jakarta.

Badan Pusat Statistik, 2016. Kota Jayapura Dalam Angka 2016. Badan Pusat Statistik Kota Jayapura, Jayapura.

Ketetapan Majelis Permusyawaratan Rakyat Republik Indonesia Nomor: IV/MPR/1999 Tentang Garis-Garis Besar Haluan Negara Tahun 1999 - 2004

Keputusan Gubernur Nomor 466 Tahun 2014 tentang Persetujuan Pemberian Bantuan Dana Pembinaan Dan Pengembangan Kepada Lembaga-Lembaga Keagamaan di Provinsi Papua Tahun Anggaran 2014.
Undang-Undang No.21 Tahun 2001 tentang Otonomi Khusus bagi Provinsi Papua.

Undang-Undang No 35 Tahun 2008 tentang Penetapan Peraturan Pemerintah Pengganti Undangundang No.1 Tahun 2008 tentang perubahan atas Undang-undang No.21 Tahun 2001 tentang Otonomi Khusus bagi Provinsi Papua.

Peraturan Pemerintah Pengganti Undang-Undang No.1 Tahun 2008 tentang perubahan atas Undang-Undang Nomor 21 Tahun 2001 tentang Otonomi Khusus bagi Provinsi Papua.

Perdasus 25 Tahun 2013 tentang Pembagian Penerimaan dan Pengelolaan Dana Otonomi Khusus Papua

Peraturan Gubernur 32 Tahun 2014 tentang Petunjuk Pelaksanaan dan Penggunaan Dana Otonomi Khusus Bidang Pendidikan bagi Kabupaten/Kota di Provinsi Papua

Peraturan Gubernur Nomor 6 Tahun 2014 tentang Jaminan 
Papua Law Journal @ Volume 2 Issue 1, November 2017

Pembiayaan Pelayanan Kesehatan

Masyarakat Papua

Peraturan Gubernur Nomor 8 Tahun

2014 tentang Petunjuk Teknis

Penggunaan Dana Otonomi

Khusus Bidang Kesehatan

sebesar $\quad 15 \% \quad$ Untuk

Kabupaten/Kota se Provinsi Papua.

Peraturan Gubernur Nomor 16 Tahun 2014 tentang Pedoman
Pengelolaan Dana Program

Strategis Pembangunan Ekonomi

dan Kelembagaan Kampung

Tahun 2014.

Peraturan Gubernur Nomor 30 Tahun 2015 tentang Pengalokasian Dana Otonomi Khusus Kabupaten/Kota Se Provinsi Papua Tahun Anggaran 2015. 